\title{
Обґрунтування вирощування картоплі за технологією Streep-Till
}

\author{
В.І. Пастухов ${ }^{1}$, Р.В, Кириченко ${ }^{2}$ М.В. Бакум ${ }^{3}$, М.М. Крекот ${ }^{4}$, \\ О.М. Могильна ${ }^{5}$, О.В. Мельник ${ }^{5}$, В.В. Калашник ${ }^{6}$ В.І. Михайлін ${ }^{5}$ \\ Харківський національний технічний університет \\ сільського господарства імені Петра Василенка (м. Харків, Украӥна), \\ email: 'pastukhov.v@ukr.net, ${ }^{2}$ kirichenkoromeo@ukr.net, ${ }^{3}$ bakymshm@khntusg.info, \\ ${ }^{4}$ krekotshm@khntusg.info, 6 kalach98ak@gmail.com, \\ ${ }^{5}$ Iнститут овочівництва і баштанництва Національної академії аграрних наук \\ (с. Селекційне, Харківський район, Харківська область, Україна), \\ email: ovoch.iob@gmail.com
}

\begin{abstract}
Дослідження присвячені розробці енергозберігаючої екологічноощадної технології Streep-Till вирощування картоплі на поверхні поля під шаром мульчі (соломи).

Традиційна технологія вирощування картоплі потребує значних енергетичних витрат, пов'язаних з використанням сільськогосподарської техніки. Несприятливі погодні умови останніх років суттєво знизили врожайність і товарність цієї культури.

Під час виконання технологічних операцій сучасні машинно-тракторні агрегати переущільнюють ґрунт, погіршують водно-повітряний баланс, що знижує його родючість. Сучасні промислові технології передбачають широке застосування пестицидів при вирощуванні картоплі. Крім того, зміна кліматичних умов в останні роки привели до підвищення температур повітря і ґрунту в період вегетації рослин. Перелічені фактори негативно впливають на врожайність та товарність картоплі.

Розроблена екологічноощадна технологія Streep-Till механізованого вирощування картоплі включає розкладання посадочного матеріалу картоплі на поверхню поля і накривання усієї площі поля, включаючи міжряддя, шаром мульчі (соломи) і виключає міжрядний обробіток ґрунту під час вегетації.

Збирання врожаю картоплі спрощується і полягає лише у підбиранні бульб картоплі з поверхні поля картоплезбиральними машинами.

Запропонована технологія забезпечує оптимальний температурний режим для формування урожаю картоплі, мінімізує вплив техніки на ґрунт, застосування пестицидів і зменшує енерговитрати.
\end{abstract}

Ключові слова: картопля, екологічноощадна, енергозберігаюча технологія, технічні засоби, шар мульчі, солома, грунт, температура, урожайність.

Вступ. Зменшення запасів гумусу, збільшення енерговитрат, питання екології, а також збереження в ґрунті вологи (ії дефріцит в умовах малосніжних зим спостерігається сьогодні в багатьох країнах) вимагає більш ефективних і екологічних систем землеробства, а відповідно, і глобального перегляду технологій господарювання. Тому сучасне сільське господарство повинно швидко пристосовуватися до нових обставин, трансформуючи підходи.

За багато років по інтенсивності механічного впливу на ґрунт системи землеробства пройшли від посіву зернових в «лунки» до сучасних технологій StripTill [1].

Виробництво сільськогосподарських культур за зберігаючою технологією Strip-till існує близько 15 років і набуло широкого поширення в США, Канаді, європейських країнах. За такою технологією вирощуються кукурудза, соя, цукрові буряки, бавовна, соняшник, картопля, а також томати, капуста і багато інших овочевих культур. Strip-till дослівно означає «смуговий обробіток ґрунту». Ця технологія є компромісом між класичною і нульовою обробками ґрунту (No-till). При Strip-till поле обробляється лише смугами і засівається сільськогосподарськими культурами.

Постановка проблеми. В останні роки аграрії Україні не задовольняють потреби населення у картоплі, але при цьому вони не горять бажанням вирощувати цю культуру. Серед причин, які стримують виробництво картоплі $\epsilon$ великі питомі енергозатрати на ії вирощування. При традиційній технології вирощування це пов'язано з великим обсягом енергозатратних операцій з відвальної обробки ґрунту, підготовки ґрунту до садіння, міжрядної культивації, підгортання кущів і викопування бульбоплодів [2-4].

За даними Української асоціації виробників картоплі [5] доля прибутку виробника від реалізації врожаю складає від 12\% - через посередників (виробник - закупівельник - реалізатор) до 35\% при безпосередньому постачанні «виробник - 
магазин». Збільшення маржі виробника можливо досягти за рахунок суттєвого зниження собівартості продукції. Частково зменшити витрати на виробництво картоплі можливо за рахунок застосування гербіцидів, але при цьому знижується якість бульбоплодів і збільшуються втрати під час зберігання [6, 7]. Значно більшого зниження собівартості виробництва картоплі можна досягти внаслідок виключення окремих технологічних операцій при вирощуванні.

Крім того, середня врожайність картоплі в Степовій та Лісостеповій зонах України, за останні п'ять років, становить $12 . .17$ т/га, в той час, як в країнах Західної Європи $27 . .29$ т/га, а в Нідерландах отримають урожаї більші 50 т/га. Збільшення урожайності картоплі досягається за рахунок підбору високопродуктивних сортів для конкретних умов вирощування та підготовки якісного садильного матеріалу, вибору ділянок поля з легким за гранулометричним складом та високою родючістю ґрунтів, вибором попередників, обґрунтованим внесенням органічних та мінеральних добрив, використанням післяжнивних сидератів та підвищення якості виконання усіх складових технології вирощування [8-14].

Зміна клімату в останні роки призвела до зменшення кількості опадів та підвищення температури повітря. Оптимальні умови для формування столонів та бульб картоплі створюються при температурі $16 \ldots 20^{\circ} \mathrm{C}$ та вологості ґрунту $70 . .75 \%$. Температура $25^{\circ} \mathrm{C} \epsilon$ критичною для вегетації картоплі, а при температурі $29 . . .30^{\circ} \mathrm{C}$ ріст рослин припиняється і формування урожаю не відбувається.

Високі температури повітря і недостатня кількість опадів наприкінці травня-початку червня та з середини липня до середини серпня, що мало місце в останні роки, призвели до різкого зниження урожайності середньостиглих та пізньостиглих сортів, а в деякі роки - ранньостиглих та середньоранніх сортів картоплі. Загроза пізніх весняних заморозків не дає змоги здійснювати раннє садіння. Тому в різних регіонах проводяться пошуки способів створення оптимальних температурних умов для росту та розвитку рослин картоплі.

Крім того багаторазовий прохід машиннотракторних агрегатів по полю під час вирощування картоплі за сучасними промисловими технологіями веде до значного переущільнення ґрунту, зміни його структурного складу, порушення водно-повітряного режиму, що негативно впливає на розвиток бульб. Тому створення умов для формування високих урожаїв якісної картоплі з застосуванням енергонасиченої важкої техніки та в умовах зміни клімату є актуальним питанням і не лише для України.

Аналіз останніх досліджень і публікацій. Найбільш ефективними є способи застосування укривних та мульчувальних матеріалів органіч- ного та неорганічного походження (солома злакових культур, скошена трава, листя дерев, кора хвойних дерев, пластикові матеріали, плівка та інші). Мульча дозволяє змінювати мікроклімат в насадженнях та сприяэ формуванню урожаю сільськогосподарських культур, в тому числі картоплі [15-20], тому серед суттєвих переваг застосування мульчі слід відмітити наступні:

- шар мульчі підтримує сприятливий температурний режим вегетації рослин;

- створює умови для накопичування вологи у верхньому шарі грунту, завдяки конденсації під час перепаду нічної і денної температур;

- затримує випаровування вологи з ґрунту;

- не дає можливості проростанню бур'янам;

- виключає операції міжрядного обробітку і тим самим мінімізує енергетичне навантаження на ґрунт;

- бульби картоплі під час їх росту розташовуються у верхньому шарі і навіть на поверхні ґрунту, що зменшує енерговитрати і втрати врожаю під час збирання;

- вважаючи, що на бульби практично не діє опір ґрунту при їх рості, їх форма подібна кулястій або еліпсоподібній, що придає їм привабливий товарний вигляд і зменшує втрати продукту при їх очищенні;

- пухкий шар ґрунтового середовища, в якому знаходяться бульби, сприяє якісній сепарації вороху і очищенню бульбоплодів від ґрунту під час збирання.

Більш радикальних змін технології вирощування картоплі набувають на огородніх ділянках. Особливої уваги заслуговує вирощування картоплі на поверхні поля під шаром мульчі. Необґрунтованість параметрів такого способу поки-що не гарантує отримання сталих високих врожаїв якісної картоплі, але показує можливість кардинального зменшення енергозатрат при її вирощуванні. Для його ефективного використання необхідне повноцінне обґрунтування параметрів шару мульчі спроможного забезпечувати сприятливий температурний режим для формування високих урожаїв якісної картоплі в умовах зміни клімату [21, 22].

Аналізуючи сучасні механізовані технології вирощування картоплі та досвід вирощування бульбоплодів [4-20], був запропонований спосіб механізованого вирощування (виробництва) картоплі на поверхні поля під шаром мульчі [23] і виконане економічне обґрунтування технології за цим способом [24]. Розрахунки показали значну економію енерго-трудовитрат при виконанні основних технологічних операцій за запропонованою технологією в порівнянні с традиційною. Але при детальному аналізі технології було визначено витрати на допоміжних операціях, якими є: тюкування соломи після збирання зернових колосових культур, навантажування у транспортні 
засоби, транспортування тюків до місця зберігання і їх розвантажування. Надалі навесні зворотній процес: навантажування, транспортування i розвантажування тюків на місці посадки картоплі. Розрахунки показали, що економія енерго- і трудовитрат невелюється цими допоміжними операціями. Вирішити цю проблему можна в системі землеробства «Міх Сropp» з застосуванням технології «Strip Till».

Подальше поглиблення вивчення даного питання дозволить вирішити актуальні проблеми картоплярства.

Мета досліджень. Обґрунтування основних складових енергозберігаючої механізованої технології Strip-Till вирощування картоплі на поверхні поля під шаром мульчі системі землеробста «Mix Cropp».

Результати досліджень. Вирощувати картоплю доцільно на полі після озимих зернових культур, які $є$ добрими попередниками. Після збирання зернових на полі залишають валки соломи, якою в подальшому вкривається картопля, висаджена на поверхню ґрунту. Валки соломи здвоюють, строюють, в залежності від врожайності соломи, і розташовують паралельно один одному 3 інтервалом, який дорівнює, або кратний ширині захвату картоплесаджалки (рис. 1). Це зменшує як витрати на збирання незернової частини врожаю зернових культур, так і затрати на транспортування соломи для накривання картоплі.

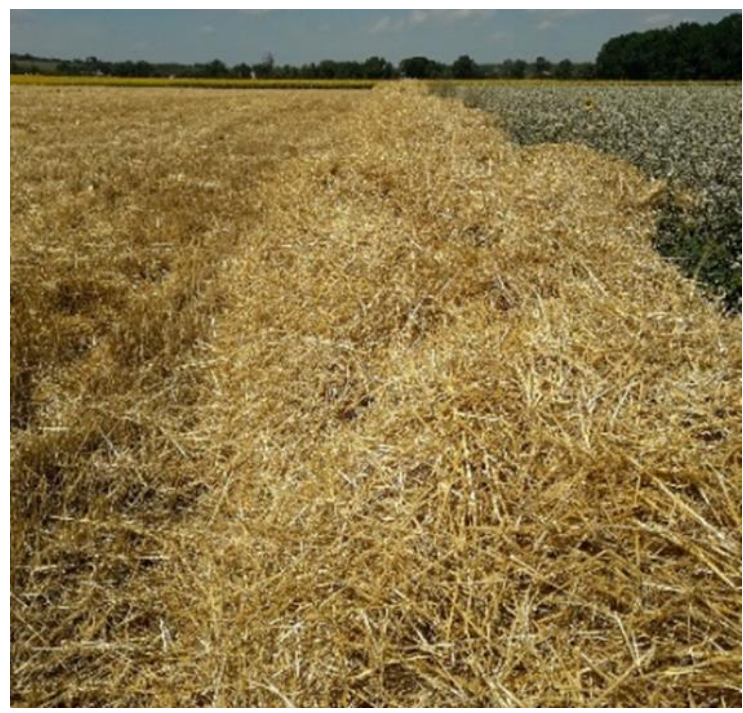

Рис. 1. Здвоєний валок соломи після збирання озимої пшениці

Для посадки картоплі використовують серійні картоплесаджалки. При налагоджені їх до роботи сошники саджалок встановлюють таким чином, щоб вони висаджували бульби в рядки на поверхню поля без заробки їх у ґрунт. При цьому загортачі з саджалок доцільно зняти (рис. 2).

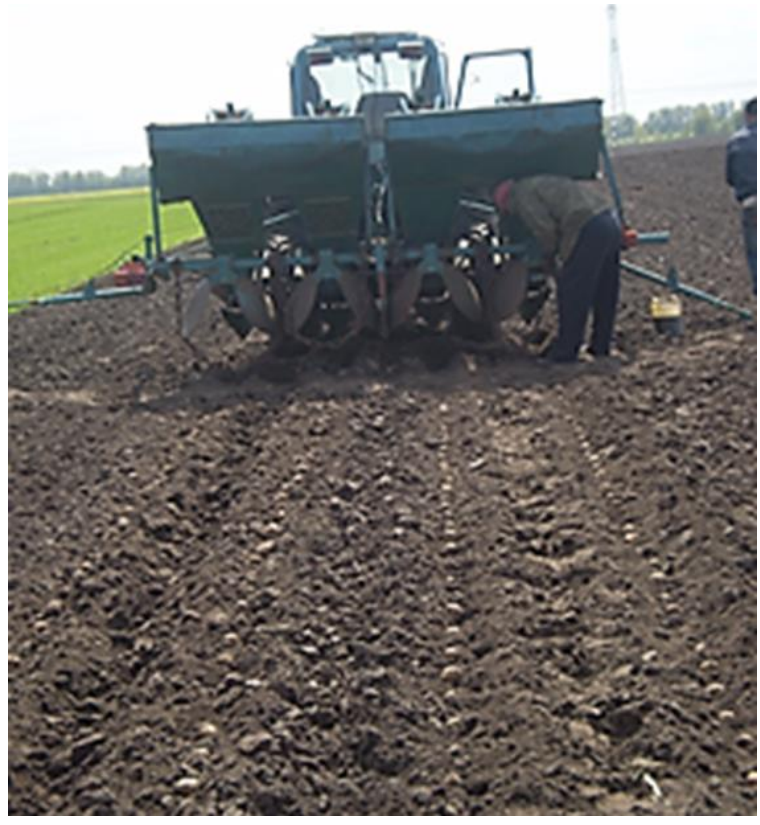

Рис. 2. Садіння бульб картоплесаджалкою з піднятими сошниками

Висаджені таким чином бульби накривають суцільним шаром мульчі (рис. 3). При зберіганні соломи на краях поля, для зменшення витрат на транспортування, її можна розкидати за допомогою кузовних розрихлювачів-розкидачів (рис. 4), якщо ширина коліс розкидачів співпадає з міжряддями висадженої картоплі, або кузовних кормороздавачів, які подають солому із кузова через боковий розвантажувальний пристрій, рухаючись по незасадженій ділянці поля поряд з останнім рядком (рис. 5).

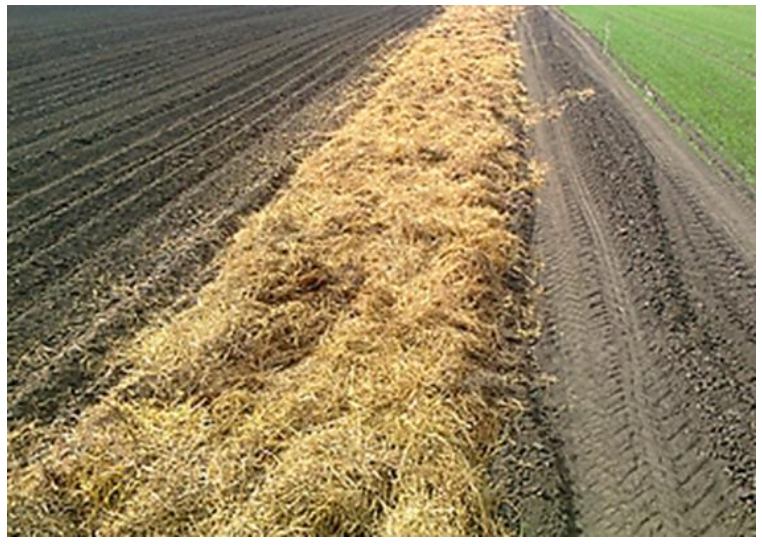

Рис. 3. Укриття бульб шаром мульчі соломи

У випадку, коли солома зберігалась з осені на полі у валках, укривання картоплі виконується 3 валка за допомогою механізованого засобу, який розроблений на кафедрі сільськогосподарських машин ХНТУСГ і зараз знаходиться на етапі патентування. 


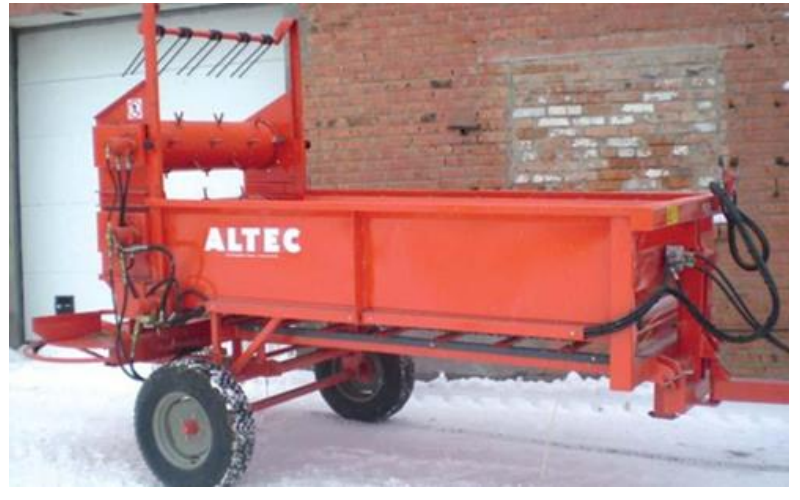

Рис. 4. Кузовний розрихлювач-розкидач тюків Altec DT120RA

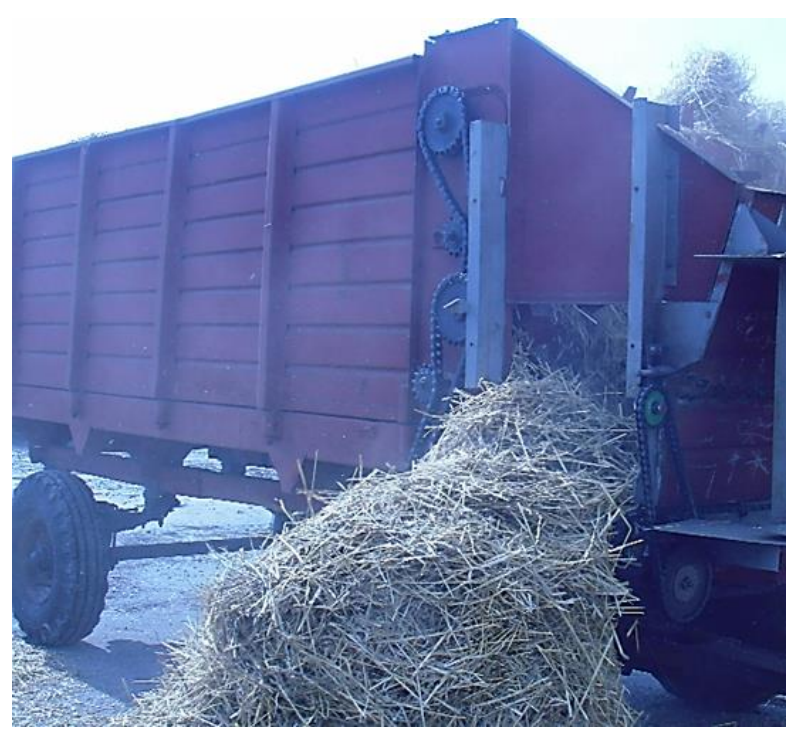

Рис. 5. Кузовний кормороздавач КТУ-10

Шар соломи повинен надійно захищати молоді бульби не лише від потрапляння на них сонячних променів, а також і від низьких (весною) та високих (влітку) температур. Одночасно такий шар соломи буде успішно зберігати ґрунтову вологу та дощову воду від випаровування. Це в більшості випадків в повній мірі забезпечить отримання високих урожаїв картоплі без додаткового зрошення посівів. Шар соломи захищає висаджені бульби від заморозків, що дозволяє вирощувати картоплю у більш ранні строки, навіть у північних районах.

Догляд за картоплею під час вегетації зменшується з декількох причин. По-перше, рослини бур'янів, на відміну від картоплі, через шар соломи не проростають і гинуть, тому відпадає необхідність їх механічного або хімічного знищення. Це зменшує витрати на паливо (енерговитрати) i гербіциди. По-друге, міжряддя рослин, вкриті соломою, не пересихають і не покриваються кіркою, тому відпадає необхідність їх розпушування, що дає економію енерговитрат. По-третє, для отримання високого урожаю картоплі за період вегетації за традиційною технологією необхідно провести мінімум два обгортання картоплі, тобто створити в зоні розташування бульб розущільнене пухке середовище для доступу повітря і можливості збільшення бульбоплодів. При накритті бульб соломою таке середовище створюється 3 самого початку на весь період розвитку, що також зменшує енерговитрати на вирощування картоплі. Виключення перерахованих механізованих операцій, окрім відміченої економії енерговитрат, знижує кількість проходів по полю машинно-тракторних агрегатів, що веде до зменшення ущільнення ґрунту і сприятливо діє на розвиток кореневої системи рослин.

При такому способі вирощування коріння картоплі, висадженої на поверхню поля, проникає у ґрунт і забезпечує ріст як самої рослини картоплі - бадилля, яке проростає через шар соломи у вигляді куща стебел (рис. 6), так і столонів, на яких виростають нові бульби картоплі, які теж знаходяться на поверхні поля під шаром соломи. Шар соломи в цей період регулює температурний режим росту бульб картоплі. Навіть при денній температурі, яка перевищує $30^{\circ} \mathrm{C}$ (рубіж, при якому ріст бульб припиняється), температура під шаром соломи буде значно нижчою (рис. 7). Це забезпечує рівномірний, неперервний розвиток усіх утворених бульб і тим самим збільшення врожайності і товарності вирощеної картоплі.

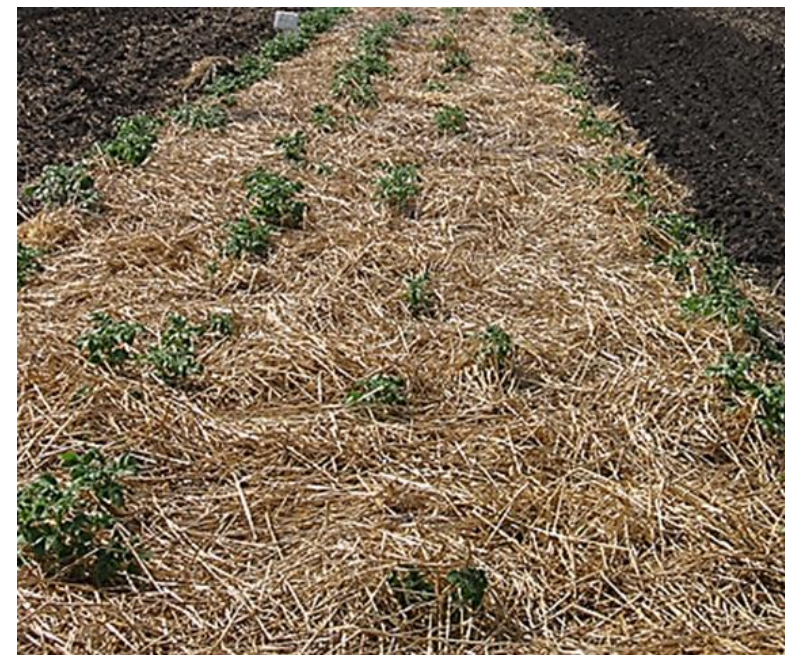

Рис. 6. Проростання бадилля картоплі через шар соломи

При збиранні бульб картоплі вирощеної за запропонованою технологією, спочатку на поле заїжджають агрегати для підбирання соломи, які згрібають шар соломи з рядків картоплі і складають її у валки (рис. 8) або пресують чи розсіюють на звільнені від урожаю загінки поля. 


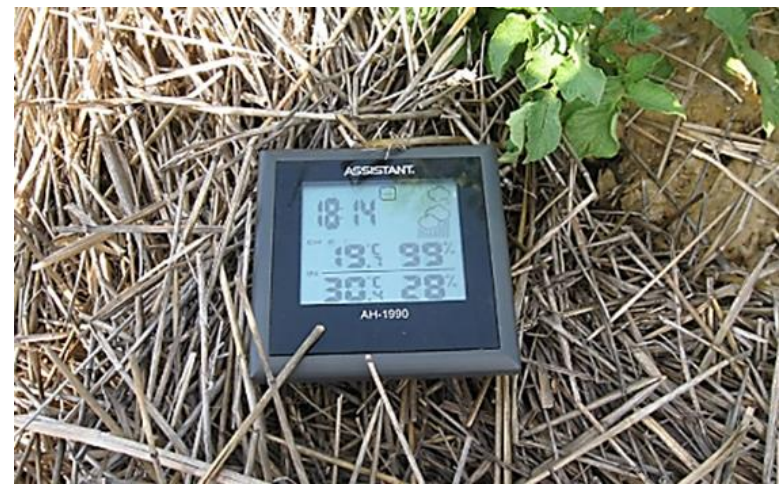

Рис. 7. Вимірювання температури на поверхні поля під шаром соломи

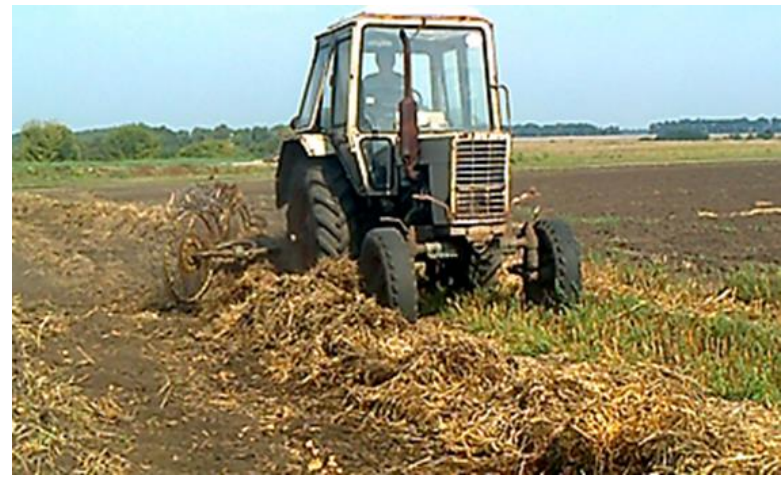

Рис. 8. Згрібання шару соломи з рядків картоплі

Після звільнення від соломи рядки картоплі, яка знаходиться на поверхні поля, підбираються картоплекопачами або картоплезбиральними комбайнами без значного заглиблення (лише на $1 . .2 \mathrm{~cm}$, для забезпечення повного підбирання бульб і виключення можливості їх травмування лемішами) (рис. 9). Навантаження на збиральні машини при такому способові вирощування суттєво зменшується, що забезпечує значне збільшення продуктивності збиральної техніки і зниження енергозатрат та травмування бульб картоплі.

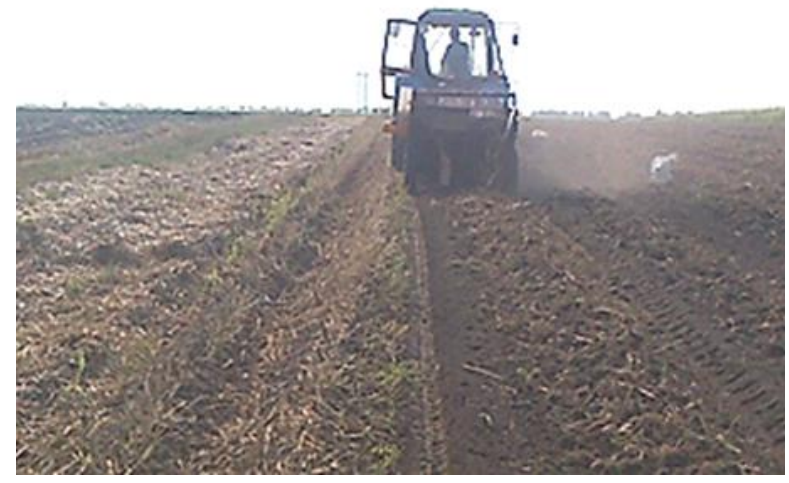

Рис. 9. Збирання картоплі з поверхні поля після зняття шару соломи
Таким чином, аналіз основних складових запропонованої енергозберігаючої екологічноощадної технології вирощування картоплі на поверхні поля показує, що ефективність її використання в першу чергу залежить від спроможності мульчувального шару соломи забезпечити сприятливі температурні умови для формування великих урожаїв якісної картоплі. В якості мульчувального матеріалу в сучасному виробництві найбільш доступною $є$ солома зернових культур.

\section{Висновки.}

1. Польовими дослідженнями 2015 - 2020 рр. встановлено що шар соломи товщиною 20 - 25 см створює оптимальний температурний режим в зоні формування столонів і бульб картоплі під шаром мульчі не залежно від температури навколишнього середовища (від ранньовесняних заморозків до літньої спеки) для отримання високих урожаїв якісної картоплі.

2. Розроблена енергозберігаюча екологічноощадна технологія Streep-Till вирощування картоплі під шаром мульчі виключає:

-обробіток ґрунту перед посадкою насіннєвого матеріалу картоплі, що дозволяє її ефективно вирощувати на різних типах ґрунтів;

- міжрядний обробіток ґрунту та застосування гербіцидів для боротьби з бур'янами, так як вони не проростають через визначену товщину шару мульчі;

3. Впровадження запропонованої технології забезпечує зменшення:

- витрат на транспортування соломи та накривання висадженої картоплі за рахунок того, що вона залишається на полі після збирання зернових культур;

- витрат на збирання врожаю картоплі за рахунок того, що вона знаходиться на поверхні поля;

- кількості проходів машинних агрегатів по полю, що зменшує ущільнення ґрунту і покращує розвиток кореневої системи рослин.

\section{Література:}

1. Мельник В.И. Эволюция систем земледелия - взгляд в будущее / В.И. Мельник // Земледелие, - 2015. №1. С. 8-12.

2. Проблеми розвитку ринку картоплі в Україні / В.П. Рудь, О.В. Муравйова, В.В. Сидора // Овочівництво і баштанництво: міжвідомчий тематичний науковий збірник, ІОБ НААН. - X: ВП «Плеяда», 2015. - Вип.61. С. 193-199.

3. Басиев С.С. Сидеральные культуры - повышение плодородия почвы и урожая картофеля / С.С. Басиев // Земледелие, №1, - 2008, - C. 33.

4. Мельцаев И.Г. Урожай и качество картофеля зависят от технологии картофеля / И.Г. Мельцаев // Картофель и овощи. 2004, № 3. - С. 6-7. 
5. Василенко А.Л. Перспективи розвитку галузі картоплярства в Україні / А.Л. Василенко // Картоплярство України. - 2012. - № 3 (4). - С. 5760. - Режим доступу: http://nbuv.gov.ua/UJRN/ kartu_2012 3-4_13

6. Щербинин А.Н. Картофель можно выращивать без гербицидов / А.Н. Щербинин, Х.К. Албегов, М.А. Бзиков // Картофель и овощи. 1999, № 5. - C. 7-8.

7. Bhardwaj K. Effect of legume grech manuzino on nitrogen mineralization and gom, microbiological properties in acid zice soil / K. Bhardwaj, N. Datte // Biology and Fertility soil. 1995, № 1. - Р. 19.

8. Корниенко С.И. Изменение климата и его влияние на технологию выращивания картофеля / С.И. Корниенко, В.А. Муравьев, А.В. Мельник // Картофель и овощи. 2015, №2 (3). - С. 26-28.

9. Котиков М.В. Влияние различных видов удобрений на урожай и качество картофеля / М.В. Котиков, Ю.Ю. Васин // Агрохимический вестник. 2007, № 1. - С. 17-18.

10. Бердников А.М. Возделывание картофеля с использованием сидератов / А.М. Бердников, В.П. Косьянчук // Земледелие. 1999. №4. - C. 26-29.

11. Буряков А.Т. Приемы агротехники картофреля // Картофрель и овощи. 2004, № 3. - С. 25-26.

12. Лысенко Ю.Н. Новый способ бессменного возделывания картофеля // Картофель и овощи. 2004, № 3. - C. 21-24.

13. Балабанов П.Р. Агротехнологические нововведения ресурсосберегающего производства картофеля / П.Р. Балабанов // Аграрный вестник Урала. - 2005. - №3 (27). - С. 44-63.

14. Dzyuba O., Дослідження впливу конструктивно-режимних параметрів на енергоємність плуга ПЛН-3-35 / Oleg Dzyuba, Anaholy Dzyuba, Anatoly Polyakov, Vadim Volokh, Roman Antoshchenkov, Anatolii Mykhailov // Східно-Європейський журнал передових технологій. - 2019. T. 3, N 1 (99). - С. 55-65. - Режим доступу: DOI: 10.15587/1729-4061.2019.169903.

15. Zribi W. Efficiency of inorganic and organic mulching materials for soil evaporation control / W. Zribi, R. Aragüés, E. Medina, J.M. Faci // Soil and Tillage Research. Vol. 148, 2015. - P. 40 - 45. DOI: 10.1016 / j.still.2014.12.003

16. Marie lannotti. The Beginner's Guide to Growing Heirloom Vegetables: The 100 Easiest-toGrow, Tastiest Vegetables for Your Garden Paperback. / Portland, Or.; London: Timber, 2012. - 252 p.

17. Паламарчук I.I. Продуктивність та динаміка плодоношення кабачка за мульчування ґрунту в умовах правобережного лісостепу / І.І. Паламарчук // Овочівництво і баштанництво: міжвідомчий тематичний науковий збірник, ІОБ НААН. - Х: ВП «Плеяда», 2013. - Вип.59. С. 226-234.
18. Goel Lalit Investigations on effectiveness of wheat and rice straw mulches on moisture retention in potato crop / Lalit Goel, Vijay Shankar, R.K. Sharma // International Journal of Recycling of Organic Waste in Agriculture. - Springer Berlin Heidelberg. - 2019, Vol. 8, Suppl. 1. - P. 345-356. - DOI: 10.1007/s40093-019-00307-6.

19. Выращивание картофеля под агроволокном / Н.Г. Резник, И.М. Кеньо, З.Д. Сыч // Овочівництво і баштанництво: міжвідомчий тематичний науковий збірник, ІОБ НААН. - Х: ВП «Плеяда», 2013. - Вип.59. С. 244-248.

20. Mohammad Abdul Kader. Mulching typeinduced soil moisture and temperature regimes and water use efficiency of soybean under rain-fed condition in central Japan / Mohammad Abdul Kader, Masateru Senge, Mohammad Abdul Mojid, Kimihito Nakamura // International Soil and Water Conservation Research. - 2017, Vol. 5, Issue 4. - P. 302-308. - DOI: 10.1016/j.iswcr.2017.08.001.

21. V. Pastukhov, O. Mogilnay, M. Bakum, O. Melnyk, I. Grabar, R. Kyrychenko, M. Krekot, H. Tesliuk, V. Boiko, I. Sysenko. Energy-efficient and ecologically friendly technology for growing potatoes under straw mulch / Ukrainian Journal of Ecology, 317-324, DOI: 10.15421/2020_50.

22. Пастухов В.І. Дослідження агрофонів як фактора впливу при вирощуванні картоплі на поверхні поля під шаром соломи / В.І. Пастухов, О.М. Могильна, О.В. Мельник, Р.В. Кириченко, М.В. Бакум // Теоретичні і практичні аспекти розвитку галузі овочівництва в сучасних умовах: Матеріали III міжнародної науково-практичної конференції, ІОБ НААН. Вінниця: ТОВ «ТВОРИ», 2020. T. 2. C 137-139.

23. Спосіб механізованого вирощування картоплі на поверхні поля: пат. 81963 Україна. № u201302420; заявл. 26.02.2013; опубл. 10.07.2013, Бюл. № 13. 6 с.

24. Пастухов В.І. Обґрунтування технології вирощування картоплі на поверхні поля під шаром соломи / В. І. Пастухов, Н. В. Бакум, А. І. Вісхам, М. М. Майборода, Д. В. Крохмаль, І. О. Головін, В. В. Адамчук, В. Г. Присяжний, А. Н. Борис, С. І. Корнієнко, О. М. Могильна, В. О. Муравйов, О. В. Мельник // Вісник ХНТУСГ ім. П. Василенка «Механізація сільськогосподарського виробництва». Харків: ХНТУСГ, 2016 - Вип. 173. - C.5-13.

\section{References:}

1. Mel'nik V.I. (2015) Evolyutsiya sistem zemledeliya - vzglyad v budushcheye. Zemledeliye. (1). pp. 8-12.

2. Rud' V.P., Muravyova O.V. and Sydora V.V. (2015) Problemy rozvytku rynku kartopli v Ukrayini Ovochivnytstvo i bashtannytstvo: mizhvidomchyy 
tematychnyy naukovyy zbirnyk, IOB NAAN. Kharkiv: VP «Pleyada». (61). pp. 193-199.

3. Basiyev S.S. (2008) Sideral'nyye kul'tury povysheniye plodorodiya pochvy $i$ urozhaya kartofelya. Zemledeliye, (1). $33 \mathrm{p}$.

4. Mel'tsayev I.G. (2004) Urozhay i kachestvo kartofelya zavisyat ot tekhnologii kartofelya. Kartofel' i ovoshchi, (3). pp. 6-7.

5. Vasylenko A.L. (2012) Perspektyvy rozvytku haluzi kartoplyarstva $v$ Ukrayini. Kartoplyarstvo Ukrayiny. (3 (4)). pp. 57-60.

6. Shcherbinin A.N., Albegov K.K. and M.A. Bzikov (1999) Kartofel' mozhno vyrashchivat' bez gerbitsidov. Kartofel' i ovoshchi, (5). pp. 7-8.

7. Bhardwaj K., Datte N. (1995) Effect of legume grech manuzino on nitrogen mineralization and gom, microbiological properties in acid zice soil. Biology and Fertility soil, (1). $19 \mathrm{p}$.

8. Korniyenko S.I., Murav'yev V.A. and Mel'nik A.V. (2015) Izmeneniye klimata i yego vliyaniye na tekhnologiyu vyrashchivaniya kartofelya. Kartofel' i ovoshchi, (2 (3)). pp. 26-28.

9. Kotikov M.V., Vasin Y.Y. (2007) Vliyaniye razlichnykh vidov udobreniy na urozhay $i$ kachestvo kartofelya. Agrokhimicheskiy vestnik, (1). pp. 17-18.

10. Berdnikov A.M. , Kos'yanchuk V.P. (1999) Vozdelyvaniye kartofelya $s$ ispol'zovaniyem sideratov. Zemledeliye. (4). pp. 26-29.

11. Buryakov A.T. (2004) Priyemy agrotekhniki kartofelya. Kartofel' i ovoshchi, (3). pp. 25-26.

12. Lysenko Y.N. (2004) Novyy sposob bessmennogo vozdelyvaniya kartofelya. Kartofel' i ovoshchi, (3). pp. 21-24.

13. Balabanov P.R. (2005) Agrotekhnologicheskiye novovvedeniya resursosberegayushchego proizvodstva kartofelya. Agrarnyy vestnik Urala. (3 (27)). pp. 44-63.

14. Dzyuba O. et al. (2019) Doslidzhennya vplyvu konstruktyvno-rezhymnykh parametriv na enerhoyemnist' pluha PLN-3-35. SkhidnoYevropeys'kyy zhurnal peredovykh tekhnolohiy. t. 3, (1(99)), pp. 55-65.

15. Zribi W. et al. (2015) Efficiency of inorganic and organic mulching materials for soil evaporation contro. Soil and Tillage Research. (148). pp. 40 - 45.

16. Marie Iannotti (2012) The Beginner's Guide to Growing Heirloom Vegetables: The 100 Easiestto-Grow, Tastiest Vegetables for Your Garden Paperback. London: Timber. $252 \mathrm{p}$.

17. Palamarchuk I.I. (2013) Produktyvnist' ta dynamika plodonoshennya kabachka za mul'chuvannya gruntu $v$ umovakh pravoberezhnoho lisostepu. Ovochivnytstvo i bashtannytstvo: mizhvidomchyy tematychnyy naukovyy zbirnyk, IOB NAAN. Kharkiv: VP «Pleyada». (59). pp. 226-234.

18. Goel Lalit, Vijay Shankar and Sharma R.K. (2019) Investigations on effectiveness of wheat and rice straw mulches on moisture retention in potato crop. International Journal of Recycling of Organic Waste in Agriculture, (8(1)). pp. 345-356.

19. Reznik N.G., Ken'o I.M. and Sych Z.D. (2013) Vyrashchivaniye kartofelya pod agrovoloknom. Ovochívnitstvo í bashtannitstvo: mízhvídomchiy tematichniy naukoviy zbírnik, İB NAAN. Kharkiv: VP «Pleyada», (59). pp. 244-248.

20. Mohammad Abdul Kader et al. (2017) Mulching type-induced soil moisture and temperature regimes and water use efficiency of soybean under rain-fed condition in central Japan. International Soil and Water Conservation Research, (5( 4)). pp. 302-308.

21. Pastukhov V. et al. (2020) Energy-efficient and ecologically friendly technology for growing potatoes under straw mulch. Ukrainian Journal of Ecology, (10(1)) pp. 317-324.

22. Pastukhov V.I. et al. (2020) Doslidzhennya ahrofoniv yak faktora vplyvu pry vyroshchuvanni kartopli na poverkhni polya pid sharom solomy. Teoretychni i praktychni aspekty rozvytku haluzi ovochivnytstva v suchasnykh umovakh: Materialy III mizhnarodnoyi naukovo-praktychnoyi konferentsiyi, IOB NAAN. Vinnytsya: TOV «TVORY», (2). pp. 137-139.

23. Sposib mekhanizovanoho vyroshchuvannya kartopli na poverkhni polya: pat. 81963 Ukrayina. № u201302420; zayavl. 26.02.2013; opubl. 10.07.2013, Byul. № 13.

24. Pastukhov V.I. et al. (2016) Obgruntuvannya tekhnolohiyi vyroshchuvannya kartopli na poverkhni polya pid sharom solomy. Visnyk KHNTUS·H im. P. Vasylenka «Mekhanizatsiya sil's'kohospodars'koho vyrobnytstva». Kharkiv: KHNTUSH,(173). pp.5-13.

\section{Аннотация}

\section{Обоснование выращивания картофеля по технологии Streep-Till}

\section{В.И. Пастухов, Р.В, Кириченко, Н.В. Бакум, Н.Н. Крекот, Е.М. Могильная, А.В. Мельник, В.В. Калашник}

Исследования посвящены разработке энергосберегающей экологосберегающей технологии Streep-Till выращивания картошки на поверхности поля под слоем мульчи (соломы).

Традиционная технология выращивания картофеля требует значительных энергетических и трудовых затрат. Неблагоприятные погодные условия последних лет существенно снизили урожайность и товарность этой культуры. 
При выполнении технологических операций современные машинно-тракторные агрегаты переуплотняют почву, ухудшают водно-воздушный баланс, снижают ее плодородие. Современные промышленные технологии предусматривают широкое применение пестицидов при выращивании картофеля. Кроме того, изменение климатических условий в последние годы привели к повышению температур воздуха и почвы в период вегетации растений. Перечисленные факторы негативно влияют на урожайность и товарность картофеля.

Разработанная экологосберегающая технология Streep-Till механизированного выращивания картофеля включает разложение посадочного материала картофеля на поверхность поля и накрыте всей площади поля, включая междурядья слоем мульчи (соломы) и исключает междурядную обработку почвы во время вегетации.

Сбор урожая картофеля упрощается и состоит только в подборе клубней картофеля с поверхности поля картофелеуборочными машинами.

Предложенная технология обеспечивает оптимальный температурный режим для формирования урожая картофеля, минимизирует влияние техники на почву, применение пестицидов и уменьшает энергозатраты.

Ключевые слова: картофель, экологосберегающая, энергосберегающая технология, технические средства, слой мульчи, солома, почва, температура, урожайность.

\section{Abstract}

\section{Rationale for growing potatoes using Streep-Till technology}

\section{V.I. Pastukhov, R.V. Kyrychenko, M.V. Bakum, M.M. Krekot, O.M. Mogilnay, O.V. Melnyk, V.V. Kalashnyk}

The research is devoted to the development of energy-saving environmentally friendly Streep-Till technology for growing potatoes on the surface of the field under a layer of straw mulch.

Traditional potato growing technology requires significant energy costs associated with the use of agricultural machinery. Adverse weather conditions in recent years have significantly reduced the yield and marketability of this crop.

During the performance of technological operations, modern machine-tractor units overcompact the soil, worsen the water-air balance, which reduces its fertility. Modern industrial technologies provide for the widespread use of pesticides in the cultivation of potatoes. In addition, changes in climatic conditions in recent years have led to higher air and soil temperatures during the growing season. These factors negatively affect the yield and marketability of potatoes.

The developed environmentally friendly Streep-Till technology of mechanized potato cultivation includes decomposition of potato planting material on the field surface and covering the entire field area, including row spacing, a layer of straw mulch and eliminates inter-row tillage during the growing season.

Potato harvesting is simplified and consists only in picking potato tubers from the field surface by potato harvesters. The proposed technology provides the optimal temperature for the formation of potato crops, minimizes the impact of technology on the soil, the use of pesticides and reduces energy consumption.

Keywords: potatoes, environmentally friendly, energy-saving technology, technical means, layer of mulch, straw, soil, temperature, yield.

\section{Бібліографічне посилання/ Bibliography citation: Harvard}

Pastukhov, V.I. et al. (2020) 'Rationale for growing potatoes using Streep-Till technology', Engineering of nature management, (2(16), pp. $25-32$.

Подано до редакції / Received: 19.08.2020 